\title{
PENGGUNAAN KOMBINASI TEPUNG KUNYIT (Curcuma domestica) DAN JAHE (Zingiber officinale) BENTUK ENKAPSULASI DAN TANPA ENKAPSULASI TERHADAP KARAKTERISTIK USUS DAN MIKROFLORA USUS AYAM PEDAGING
}

\section{USE OF CURCUMA (Curcuma domestica) AND GINGER (Zingiber officinale) MEAL COMBINATION WITH ENCAPSULATION AND NON-ENCAPSULATION ON INTESTINAL CHARACTERISTIC, AND INTESTINAL MICROFLORAS IN BROILER}

\author{
Muhammad Halim Natsir*1, Eko Widodo ${ }^{1}$ dan Muharlien ${ }^{2}$ \\ ${ }^{1}$ Department of Animal Nutrition, Faculty of Animal Husbandry, Brawijaya University \\ Malang, 65145 \\ ${ }^{2}$ Department of Animal Production, Faculty of Animal Husbandry, Brawijaya University, Malang, 65145
}

Submitted: 5 January 2016, Accepted: 5 February 2016

\section{INTISARI}

Tujuan dari penelitian adalah mengetahui pengaruh suplementasi campuran tepung kunyit (Curcuma domestica) dan tepung jahe (Zingiber officinale) dalam bentuk tanpa enkapsulasi dan bentuk enkapsulasi terhadap karakteristik usus dan mikroflora usus ayam pedaging. Materi penelitian yang digunakan 180 ekor ayam pedaging umur 1 hari dan campuran tepung kunyit dan jahe (tanpa enkapsulasi dan terenkapsulasi) serta enkapsulan. Enkapsulan yang digunakan adalah campuran maltodekstrincasein (75\%:25\%) sebanyak 10\% dari campuran tepung kunyit dan jahe yang dikapsul, dan ditambah $\mathrm{BHT}$ 0,075\%. Metode penelitian adalah percobaan in vivo dengan menggunakan Rancangan Acak Lengkap pola searah dengan 9 perlakuan $\left(\mathrm{P}_{0}=\right.$ pakan kontrol), 2 group berdasarkan bentuk (tanpa enkapsulasi dan enkapsulasi) dengan 4 level $(0,2 ; 0,4 ; 0,6$ and $0,8 \%$ ). Hasil menunjukkan bahwa campuran tepung kunyit dan jahe dalam bentuk tanpa enkapsulasi dan dengan enkapsulasi menunjukkan perbedaan yang sangat nyata $(\mathrm{P}<0,01)$ terhadap $\mathrm{pH}$, viskositas digesta usus dan jumlah villi, tetapi tidak menunjukkan perbedaan yang nyata terhadap tinggi villi dan jumlah bakteri asam laktat, Lactobacillus sp., E. coli dan Salmonella sp.). Kesimpulan penelitian penggunaan campuran kunyit dan jahe bentuk enkapsulasi menghasilkan hasil yang lebih baik dibandingkan tanpa enkapsulasi dengan level optimum $0,8 \%$. Disarankan penggunaan campuran kunyit dan jahe sebesar $0,8 \%$ dalam pakan ayam pedaging.

(Kata kunci: Ayam pedaging, Enkapsulasi, Histologi usus, Jahe, Kunyit, Mikroflora)

\section{ABSTRACT}

The purpose of this research was to examine the use of curcuma (Curcuma domestica) and ginger (Zingiber officinale) combination with encapsulated or without encapsulated on intestinal histological and intestinal microflora in broiler. Materials used in this research were 180 day-old broiler chicks and encapsulated or non-capsulated turmeric and ginger meal mixture. Encapsulants that used was the mixture of maltodextrin-casein (75\%:25\%) which was added BHT $0.075 \% ; 10 \%$ of turmeric and ginger meal mixture. The birds were allocated in a Completely Randomized Design with 9 treatments $\left(P_{0}=\right.$ control diet), without encapsulation P1, P2, P3, P4 (0.2; 0.4; 0.6 and 0.8\%) and encapsulation P5, P6, P7, $P 8(0.2 ; 0.4 ; 0.6$ and $0.8 \%)$. The results showed that use of turmeric and ginger mixture in the form of non-encapsulation and encapsulation significantly improved $(P<0.01) \mathrm{pH}$, viscosity of digesta and the number of villi, but did not affect villi height and number of bacteria (Lactobacillus sp., E. coli and Salmonella sp.). It might be concluded that the use of turmeric and ginger mixture of capsulated form provided better results than that of non-capsulated with the optimum level of $0.8 \%$. Therefore using encapsulated form in $0.8 \%$ of the combined turmeric and ginger in broiler diet is recommended.

(Key words: Broiler chickens, Encapsulation, Ginger, Histological, Microflora, Turmeric)

\footnotetext{
${ }^{*}$ Korespondensi (corresponding author):

Telp. +62 8125240280

E-mail: emhanatsir@yahoo.com
} 


\section{Pendahuluan}

Masih tingginya angka morbidilitas dan mortalitas serta banyaknya jenis penyakit yang menyerang peternakan unggas menyebabkan peternak selalu menggantungkan pada antibiotik sintetik yang relatif mahal. Di samping itu, efek lain yang ditimbulkan akibat penggunaan antibotik sintetik adalah membahayakan kesehatan manusia yang mengkonsumsi akibat residu kimia yang ditinggalkan. Salah satu usaha yang perlu dilakukan adalah mencari pengganti antibiotik yang bersumber dari tanaman. Potensi tanaman obat di Indonesia sangat besar, seperti kunyit (Curcuma domestica) dan jahe (Zingiber officinale). Kunyit dan jahe dapat digunakan sebagai antibiotik alami karena mempunyai kemampuan dalam menekan mikroba patogen, memberikan kekebalan dan daya tahan tubuh, memperbaiki penampilan produksi dan sebagai appetizer. Bahkan kunyit dilaporkan dapat digunakan untuk menangkal virus flu burung (Chen et al., 2010). Kunyit mengandung zat kurkumin yang mempunyai khasiat sebagai antibakteri dan dapat merangsang dinding kantung empedu untuk mengeluarkan cairan empedu sehingga dapat memperlancar metabolisme lemak. Jahe selain mengandung minyak atsiri juga mengandung dua enzim pencernaan yang sangat penting, yaitu protease dan lipase. Protease berfungsi memecah protein dan lipase berfungsi memecah lemak.

Senyawa aktif yang terdapat dalam jahe dan kunyit seperti minyak atsiri, kurkumin dan oleoresin rentan hilang, berkurang atau bahkan rusak akibat penggilingan dan pemanasan (Natsir et al., 2013). Oleh karena itu perlu teknologi pengeringan tanpa merusak zat aktif yang ada di kunyit dan jahe, salah satunya dengan menggunakan teknologi enkapsulasi. Proses enkapsulasi ada penambahan enkapsulan yaitu kasein yang berfungsi untuk melindungi protein. Maltodextrin berfungsi melindungi karbohidrat serta sebagai bahan antioksidan yang dapat menghambat oksidasi lemak, sehingga dalam proses enkapsulasi zat aktif dalam kunyit dan jahe dapat dilindungi dari kerusakan.

\section{Materi dan Metode}

\section{Materi}

Ayam pedaging yang digunakan adalah strains Loghman MB Platinum umur 1 hari dengan rerata bobot badan $45,15 \pm 3,96 \mathrm{~g}$ sebanyak 180 ekor dan dipelihara selama 35 hari. Aditif pakan yang digunakan adalah campuran antara kunyit dan jahe dalam bentuk tepung dan enkapsulasi. Material enkapsulasi yang digunakan adalah maltodekstrin dan kasein dengan perbandingan $75 \%: 25 \%$ sebanyak $10 \%$ dari berat campuran kunyit dan jahe. Butyrate Hydroxyl Toluene (BHT) ditambahkan dalam proses enkapsulasi dengan menggunakan spray dryer sebanyak $0,075 \%$ dari campuran kunyit dan jahe. Pakan dan air minum diberikan secara ad libitum. Komposisi dan kandungan nutrien pakan basal ayam pedaging periode starter dan finisher dapat dilihat pada Tabel 1.

\section{Metode}

Metode penelitian yang digunakan adalah percobaan dengan Rancangan Acak Lengkap pola searah. Perlakuan yang digunakan dalam penelitian ini adalah sembilan perlakuan yang terbagi menjadi 3

Table 1. Komposisi dan kandungan nutrien pakan basal starter dan finisher (composistion and nutrient content of basal diet of stater and finisher)

\begin{tabular}{lcc}
\hline \multicolumn{1}{c}{ Bahan pakan (feed ingridients) } & Starter (\%) & Finisher (\%) \\
\hline Jagung (corn) & 60,00 & 60,00 \\
Konsentrat (consentrate) & 40,00 & 30,00 \\
Bekatul (rice brand) & - & 10,00 \\
Kandungan nutrien (nutrient content) & & \\
$\quad$ Energi metabolis (kcal/kg) (metabolic energy (kcal/kg)) & 3.161 & 3.203 \\
$\quad$ Protein kasar (\%) (crude protein (\%)) & 24,05 & 19,29 \\
$\quad$ Lemak kasar (\%) (crude fat (\%)) & 4,77 & 5,63 \\
Serat kasar (\%) (crude fiber (\%)) & 3,74 & 3,64 \\
Abu (\%) (ash (\%)) & 7,27 & 5,34 \\
\hline
\end{tabular}

* berdasarkan analisis proksimat dan uji energi metabolis di laboratorium Nutrisi dan Makanan Ternak Fakultas Peternakan Universitas Brawijaya Malang (based on proximate analysis and metabolic energy test in Laboratory of Feed And Animal Nutrition, Faculty of Animal Husbandry, Brawijaya University, Malang). 
kelompok yaitu: pakan basal tanpa penambahan aditif, empat macam pakan yang dibedakan atas tingkat penggunaan antibiotik alami tanpa proteksi (penambahan kunyit dan jahe digiling dan dikeringkan) sebesar 0,2, 0,4, 0,6 dan 0,8\% sedangkan empat macam pakan perlakuan yang lain dibedakan atas tingkat penggunaan antibiotik alami terproteksi (penambahan kunyit dan jahe terenkapsulasi) sebesar 0,2, 0,4, 0,6 dan $0,8 \%$. Setiap perlakuan diulang 4 kali dan setiap ulangan digunakan 5 ekor ayam. Pakan perlakuan selengkapnya adalah: $\mathrm{P}_{0}=$ pakan tanpa penambahan campuran kunyit dan jahe (pakan kontrol), $\mathrm{P}_{1}=$ pakan dengan penambahan campuran kunyit dan jahe giling $0,2 \%, P_{2}=$ pakan dengan penambahan campuran kunyit dan jahe giling $0,4 \%, \mathrm{P}_{3}=$ pakan dengan penambahan campuran kunyit dan jahe giling $0,6 \%, P_{4}=$ pakan dengan penambahan campuran kunyit dan jahe giling $0,8 \%, P_{5}=$ pakan dengan penambahan campuran kunyit dan jahe terenkapsulasi $0,2 \%, \quad P_{6}=$ pakan dengan penambahan campuran kunyit dan jahe terenkapsulasi $0,4 \%, \quad P_{7}=$ pakan dengan penambahan campuran kunyit dan jahe terenkapsulasi $0,6 \%, \quad P_{8}=$ pakan dengan penambahan campuran kunyit dan jahe terenkapsulasi $0,8 \%$.

Variabel yang diukur meliputi 1) $\mathrm{pH}$ usus halus dan viskositas digesta usus: diukur pada daerah ileum ayam yang baru dipotong (Van der Klis et al., 1995), 2) Jumlah dan tinggi villi diukur dan dihitung pada daerah jejenum-ileum ayam yang baru dipotong menggunakan metode intestinal mucosa histology (light microscopy) (Pelicano et al., 2005), 3) Jumlah bakteri patogen (Escherichia coli dan Salmonella sp.) dan bakteri non patogen (Lactobacillus $s p$. dan bakteri asam laktat) (Garriga et al., 1998).
Pengukuran variabel dengan cara memotong ayam setiap unit perlakuan 1 ekor sehingga total ayam yang dipotong sebanyak 36 ekor. Usus halus dipotong mulai dari $3 \mathrm{~cm}$ dari ileocaecal junction ke arah ileum sepanjang $4 \mathrm{~cm}$, kemudian kedua ujung diikat menggunakan benang jahit dimasukkan ke dalam kotak steroform yang berisi es batu, setelah sampai di laboratorium digesta dikeluarkan sebanyak $1 \mathrm{~g}$ untuk uji jumlah bakteri, $1 \mathrm{~g}$ uji $\mathrm{pH}$ dan $1 \mathrm{~g}$ uji viskositas. Potongan $4 \mathrm{~cm}$ ileum selanjutnya dikeluarkan digestanya dengan cara membersihkan dengan larutan $\mathrm{NaCl}$ fisiologis menggunakan spuit secara perlahan-lahan. Sampel usus yang sudah dikeluarkan digestanya dimasukkan dalam botol yang berisi larutan formalin $10 \%$ untuk diuji jumlah dan tinggi villi.

Data yang diperoleh dalam penelitian ini ditabulasi dan dianalisis variansi menggunakan Rancangan Acak Lengkap. Data yang berbeda nyata diuji lanjut menggunakan uji kontras ortogonal seperti tertera pada Tabel 2 (Steel dan Torrie, 1991).

\section{Hasil dan Pembahasan}

\section{Pengaruh penambahan kunyit dan jahe terhadap karakteristik usus ayam pedaging}

Pengaruh penggunaan bentuk campuran kunyit dan jahe yaitu bentuk tepung dan enkapsulasi dalam pakan terhadap karakteristik usus halus $(\mathrm{pH}$, viskositas, jumlah villi, dan tinggi villi) selama penelitian dapat dilihat pada Tabel 3 .

Hasil analisis variansi perlakuan penggunaan aditif pakan berupa campuran kunyit dan jahe dalam pakan yang diberikan dalam 2 bentuk yaitu tepung dan enkapsulasi menunjukkan adanya perbedaan yang sangat nyata $(P<0,01)$ terhadap terhadap

Tabel 2. Set kontras untuk analisis hasil penelitian (contrast set for analysis of results)

\begin{tabular}{|c|c|c|c|c|c|c|c|c|c|c|c|c|}
\hline \multirow[b]{2}{*}{ No } & \multirow{2}{*}{\multicolumn{3}{|c|}{ Kontras (contrast) }} & & \multicolumn{8}{|c|}{ Set kontras (contrast sets) } \\
\hline & & & & $P_{0}$ & $\mathrm{P}_{1}$ & $P_{2}$ & $\mathrm{P}_{3}$ & $\mathrm{P}_{4}$ & $\mathrm{P}_{5}$ & $\mathrm{P}_{6}$ & $\mathrm{P}_{7}$ & $P_{8}$ \\
\hline 1 & $P_{0}$ & vs & $P_{1}-P_{8}$ & -8 & +1 & +1 & +1 & +1 & +1 & +1 & +1 & +1 \\
\hline 2 & $\mathrm{P}_{1}-\mathrm{P}_{4}$ & vs & $P_{5}-P_{8}$ & 0 & -1 & -1 & -1 & -1 & +1 & +1 & +1 & +1 \\
\hline 3 & $\mathrm{P}_{1}$ & vs & $\mathrm{P}_{2}-\mathrm{P}_{4}$ & 0 & -3 & +1 & +1 & +1 & 0 & 0 & 0 & 0 \\
\hline 4 & $\mathrm{P}_{2}$ & vs & $\mathrm{P}_{3}-\mathrm{P}_{4}$ & 0 & 0 & -2 & +1 & +1 & 0 & 0 & 0 & 0 \\
\hline 5 & $\mathrm{P}_{3}$ & vs & $\mathrm{P}_{4}$ & 0 & 0 & 0 & -1 & +1 & 0 & 0 & 0 & 0 \\
\hline 6 & $\mathrm{P}_{5}$ & vs & $P_{6}-P_{8}$ & 0 & 0 & 0 & 0 & 0 & -3 & +1 & +1 & +1 \\
\hline 7 & $\mathrm{P}_{6}$ & vs & $\mathrm{P}_{7}-\mathrm{P}_{8}$ & 0 & 0 & 0 & 0 & 0 & 0 & -2 & +1 & +1 \\
\hline 8 & $\mathrm{P}_{7}$ & vs & $\mathrm{P}_{8}$ & 0 & 0 & 0 & 0 & 0 & 0 & 0 & -1 & +1 \\
\hline
\end{tabular}


$\mathrm{pH}$ isi usus halus, viskositas isi usus halus dan jumlah villi, tetapi memberikan pengaruh yang tidak nyata terhadap tinggi villi.

Uji antar kelompok perlakuan dengan uji kontras menunjukkan bahwa perlakuan penambahan campuran kunyit dan jahe menunjukkan adanya perbedaan yang sangat nyata $(\mathrm{P}<0,01)$ terhadap $\mathrm{pH}$ dan vikositas dibandingkan dengan pakan kontrol (kontras 1). Besarnya rerata $\mathrm{pH}$ dan viskositas kelompok perlakuan penambahan campuran kunyit dan jahe baik tepung maupun enkapsulasi adalah 6,58 dan 1,93 sedangkan pakan Kontrol 6,41 dan 2,51. Penambahan kunyit dan jahe ternyata tidak mampu menurunkan $\mathrm{pH}$ bahkan menyebabkan peningkatan $\mathrm{pH}$ ileum. Hal ini mungkin disebabkan pakan basal perlakuan menggunakan bahan konsentrat pabrik yang mengandung antibiotik berupa zinc bacitracin, sehingga semua perlakuan mengandung antibiotik. Peningkatan $\mathrm{pH}$ saluran pencernaan dilaporkan oleh Paul et al. (2007) bahwa penggunaan antibiotik virginiamycin menyebabkan $\mathrm{pH}$ saluran pencernaan meningkat.

Perlakuan penambahan campuran kunyit dan jahe bentuk tepung dalam pakan menunjukkan adanya perbedaan yang sangat nyata $(\mathrm{P}<0,01)$ terhadap $\mathrm{pH}$ dan viskositas dibandingkan penambahan campuran kunyit dan jahe bentuk enkapsulasi (Kontras 2). Besarnya rerata $\mathrm{pH}$ dan viskositas pada kelompok perlakuan penambahan campuran kunyit dan jahe bentuk tepung dan bentuk enkapsulasi masing-masing sebesar 6,45 dan 2,135 serta bentuk enkapsulasi 6,70 dan 1,724 . Besarnya rerata $\mathrm{pH}$ isi usus halus pada pakan yang diberi bentuk enkapsulasi cenderung mengalami peningkatan dibandingkan diberikan dalam bentuk tepung. Hal ini menunjukkan bahwa penambahan campuran kunyit dan jahe terenkapsulasi mempunyai efek di dalam meningkatkan $\mathrm{pH}$ usus halus didalam saluran pencernaan ayam dibandingkan pemberian bentuk tepung. Besarnya rerata viskositas isi usus halus pada pakan dengan penambahan campuran kunyit dan jahe bentuk enkapsulasi cenderung lebih dapat menurunkan viskositas isi usus halus di-bandingkan dengan pemberian bentuk tepung. Efek negatif jika viskositas isi usus halus meningkat adalah mengurangi efisiensi pencernaan dengan memperlambat laju difusi enzim endogenous untuk bereaksi dengan substrat dan nutrien serta memampatkan penyerapan dalam villi di dinding usus halus. Lavinia et al. (2009) melaporkan bahwa senyawa flavonoid dan minyak atsiri dapat menyebabkan peningkatan mukosa villi, sehingga dapat menurunkan viskositas usus. Bird (2006) melaporkan bahwa jumlah bakteri yang tidak seimbang di usus dapat menyebabkan peningkatan viskositas usus. Emamzadeh (2010) melaporkan bahwa ada hubungan linier terbalik antara nilai viskositas dengan besar TMEn.

Perlakuan antar jenis penambahan campuran kunyit dan jahe bentuk tepung menunjukkan adanya perbedaan yang sangat nyata $(P<0,01)$ terhadap $\mathrm{pH}$ dan viskositas (Kontras 3 - Kontras 5). Demikian juga dengan penambahan campuran kunyit dan jahe dalam pakan bentuk enkapsulasi dengan berbagai level menunjukkan adanya perbedaan yang sangat nyata $(P<0,01)$ terhadap $\mathrm{pH}$ dan viskositas (Kontras 6 Kontras 8).

Tabel 3. Rerata nilai pH isi usus halus, viskositas, jumlah villi dan tinggi villi dari pengaruh penambahan campuran kunyit dan jahe

(average of intestine $\mathrm{pH}$, viscosity, villi numbers and villi height by curcumaand ginger addition)

\begin{tabular}{ccccc}
\hline \hline $\begin{array}{c}\text { Perlakuan } \\
\text { treatments) }\end{array}$ & $\begin{array}{c}\text { pH isi usus } \\
\text { (intestine } p H)\end{array}$ & $\begin{array}{c}\text { Viskositas } \\
\text { (viscosity) }\end{array}$ & $\begin{array}{c}\text { Jumlah villi (per lumen) } \\
\text { (villi numbers (per lumen) })\end{array}$ & $\begin{array}{c}\text { Tinggi villi }(\mu \mathrm{m}) \\
\text { (villi height }(\mu \mathrm{m}))\end{array}$ \\
\hline $\mathrm{P}_{0}$ & $6,41^{\mathrm{bc}}$ & $2,51^{\mathrm{bc}}$ & $164,25^{\mathrm{a}}$ & 532,00 \\
$\mathrm{P}_{1}$ & $6,31^{\mathrm{b}}$ & $2,27^{\mathrm{c}}$ & $188,50^{\mathrm{ab}}$ & 529,58 \\
$\mathrm{P}_{2}$ & $6,11^{\mathrm{a}}$ & $2,15^{\mathrm{d}}$ & $180,25^{\mathrm{ab}}$ & 472,22 \\
$\mathrm{P}_{3}$ & $6,68^{\mathrm{d}}$ & $2,06^{\mathrm{bc}}$ & $178,50^{\mathrm{ab}}$ & 630,00 \\
$\mathrm{P}_{4}$ & $6,71^{\mathrm{d}}$ & $2,07^{\mathrm{a}}$ & $182,50^{\mathrm{ab}}$ & 448,33 \\
$\mathrm{P}_{5}$ & $6,62^{\mathrm{cd}}$ & $2,14^{\mathrm{b}}$ & $176,00^{\mathrm{ab}}$ & 597,14 \\
$\mathrm{P}_{6}$ & $6,93^{\mathrm{e}}$ & $1,67^{\mathrm{a}}$ & $201,75^{\mathrm{bc}}$ & 709,17 \\
$\mathrm{P}_{7}$ & $6,51^{\mathrm{bcd}}$ & $1,57^{\mathrm{a}}$ & $200,00^{\mathrm{bc}}$ & 717,14 \\
$\mathrm{P}_{8}$ & $6,73^{\mathrm{de}}$ & $1,52^{\mathrm{a}}$ & $210,00^{\mathrm{c}}$ & 574,29 \\
\hline
\end{tabular}


Uji antar kelompok perlakuan dengan uji kontras menunjukkan bahwa perlakuan penambahan campuran kunyit dan jahe menunjukkan adanya perbedaan yang sangat nyata $(P<0,01)$ terhadap jumlah villi dibandingkan dengan pakan kontrol (kontras 1). Besarnya rerata jumlah villi kelompok perlakuan penambahan campuran kunyit dan jahe baik tepung maupun enkapsulasi adalah 189,69 sedangkan pakan kontrol 164,25.

Perlakuan penambahan campuran kunyit dan jahe bentuk tepung dalam pakan menunjukkan adanya perbedaan yang sangat nyata $(P<0,01)$ terhadap jumlah villi dibandingkan penambahan campuran kunyit dan jahe bentuk enkapsulasi (Kontras 2). Besarnya rerata jumlah villi pada kelompok perlakuan penambahan campuran kunyit dan jahe bentuk tepung dan bentuk enkapsulasi masing-masing sebesar 182,44 dan 196,94. Besarnya rerata jumlah villi isi usus halus pada pakan yang diberi bentuk enkapsulasi mengalami penigkatan jumlah villi dibandingkan diberikan dalam bentuk tepung. Hal ini menunjukkan bahwa penambahan campuran kunyit dan jahe terenkapsulasi mempunyai efek meningkatnya jumlah villi di dalam saluran pencernaan ayam lebih banyak dibandingkan pemberian bentuk tepung. Peningkatan jumlah villi pada bentuk enkapsulasi disebabkan kandungan zat aktif lebih tinggi pada bentuk enkapsulasi dibandingkan bentuk tanpa enkapsulasi. Kandungan minyak atsiri, kurkumin dan oleorisin pada bentuk enkapsulasi berturutturut adalah $0,351,3,112$ dan $0,398 \%$, sedangkan bentuk tepung berturut-turut adalah $0,197,2,356$ dan 0,152\%. Lebih tingginya kandungan minyak atsiri, kurkumin dan oleorisin pada bentuk enkapsulasi membuktikan bahwa penambahan enkapsulan berupa maltodekstrin dan kasein mampu melindungi zat aktif pada kunyit dan jahe terhadap kerusakan selama proses pengeringan menjadi bentuk tepung dibandingkan bentuk tepung yang pengolahannya hanya dikeringkan tanpa adanya enkapsulan. kandungan Kandungan zat aktif berupa minyak atsiri, kurkumin dan oleorisin pada kunyit dan jahe dapat merangsang sekresi enzim pencernaan dan menghambat pertumbuhan bakteri patogen, sehingga pertumbuhan bakteri non patogen lebih optimal yang pada gilirannya dapat menjaga kesehatan villi. Pada penelitian ini meskipun antara betuk tepung dan enkapsulasi tidak menunjukkan adanya perbedaan yang nyata, namun secara numerik jumlah $E$. coli, dan Salmonella $s p$. pada bentuk enkapsulan menunjukkan data penurunan yaitu E. coli pada kelompok bentuk tepung $\left(\mathrm{P}_{1}-\mathrm{P}_{4}\right)$ rerata sebesar 3,87 log cfu/ml sedangkan bentuk enkapsulasi $\left(\mathrm{P}_{5}-\mathrm{P}_{8}\right)$ rerata sebesar 3,75 log $\mathrm{cfu} / \mathrm{ml}$, selanjutnya jumlah Salmonella $s p$. pada kelompok bentuk tepung $\left(\mathrm{P}_{1}-\mathrm{P}_{4}\right)$ rerata sebesar $4,18 \mathrm{log} \mathrm{cfu} / \mathrm{ml}$ sedangkan bentuk enkapsulasi $\left(\mathrm{P}_{5}-\mathrm{P}_{8}\right)$ rerata sebesar $4,11 \mathrm{log}$ cfu/ml. Garcı'a et al. (2007) melaporkan bahwa pemberian suplementasi asam format sebesar 5.000 dan 10.000 ppm dan dicampur dengan ekstrak tanaman sebesar 200 ppm memberikan pengaruh yang sama dengan penggunaan antibiotik (avilamycine), pertumbuhan morfologi mukosa usus dan kecernaan protein yang lebih baik. Lebih lanjut Natsir et al. (2013) melaporkan bahwa suplementasi kombinasi bawang putih dan meniran dalam pakan bentuk enkapsulasi memberikan hasil yang lebih baik dibandingkan tanpa enkapsulasi terhadap jumlah dan tinggi villi pada ayam pedaging.

Perlakuan antar jenis penambahan campuran kunyit dan jahe bentuk tepung menunjukkan adanya perbedaan yang sangat nyata $(P<0,01)$ terhadap jumlah villi (Kontras 3 - Kontras 5). Demikian juga dengan penambahan campuran kunyit dan jahe dalam pakan bentuk enkapsulasi dengan berbagai level menunjukkan adanya perbedaan yang sangat nyata $(P<0,01)$ terhadap jumlah villi (Kontras 6 - Kontras 8). Malekizadeh et al. (2012) menyatakan bahwa suplementasi jahe sebanyak $3 \%$ dalam pakan memberikan hasil yang positif terhadap penampilan produksi dan karakteristik darah pada ayam petelur periode layer.

Uji antar kelompok perlakuan dengan uji kontras menunjukkan bahwa perlakuan penambahan campuran kunyit dan jahe menunjukkan tidak ada perbedaan yang nyata terhadap tinggi villi dibandingkan dengan pakan kontrol (kontras 1). Besarnya rerata tinggi villi kelompok perlakuan penambahan campuran kunyit dan jahe baik tepung maupun enkapsulasi adalah 584,73 $\mu \mathrm{m}$ sedangkan pakan Kontrol 532,00 $\mu \mathrm{m}$.

Perlakuan penambahan campuran kunyit dan jahe bentuk tepung dalam pakan menunjukkan adanya perbedaan yang sangat nyata $(P<0,01)$ terhadap tinggi villi 
dibandingkan penambahan campuran kunyit dan jahe bentuk enkapsulasi (Kontras 2). Besarnya rerata tinggi villi pada kelompok perlakuan penambahan campuran kunyit dan jahe bentuk tepung dan bentuk enkapsulasi masing-masing sebesar 520,03 dan 649,43 $\mu \mathrm{m}$. Penigkatan tinggi villi pada pemberian bentuk enkapsulasi dibandingkan dalam bentuk tepung menunjukkan bahwa campuran kunyit dan jahe terenkapsulasi mengandung zat aktif yang lebih tinggi sehingga memberikan efek meningkatnya tinggi villi lebih tinggi didalam saluran pencernaan ayam dibandingkan pemberian bentuk tepung. Saki et al. (2012) menyatakan bahwa penambahan bawang merah dalam pakan ayam pedaging memberikan pengaruh nyata meningkatkan tinggi villi yang diukur pada umur 21 hari dan 42 hari. Lebih lanjut Zhang et al. (2005) menyatakan bahwa penggunaan minyak esensial yang terenkapsulasi $0,1 \%$ dalam pakan dapat menurunkan konversi pakan. Penurunan konversi pakan terjadi karena pakan mampu dimanfaatkan secara optimal untuk produksi dan reproduksi. Peningkatan produksi disebabkan penyerapan nutrien yang baik karena proses pencernaan meningkat akibat adanya peningkatan aktivitas enzim pencernaan seperti amilase, protease dan lipase.

Perlakuan antar jenis penambahan campuran kunyit dan jahe bentuk tepung menunjukkan tidak ada perbedaan yang nyata terhadap tinggi villi (Kontras 3 Kontras 5). Demikian juga dengan penambahan campuran kunyit dan jahe dalam pakan bentuk enkapsulasi dengan berbagai level tidak menunjukkan adanya perbedaan yang nyata terhadap tinggi villi (Kontras 6 - Kontras 8). Rahman et al. (2014) melaporkan bahwa suplementasi campuran herbal (turmeric (Curcuma Longa), fenugreek (Trigonella foenum-graecum L.) dan / atau bioflavonoid (Bio-Guard) untuk pakan ayam pedaging dapat meningkatkan tinggi dan lebar villi, kedalaman kripta dan luas permukaan dibandingkan dengan kontrol.

Pengaruh penambahan kunyit dan jahe
terhadap jumlah mikroba usus ayam
pedaging
Pengaruh penggunaan berbagai bentuk campuran kunyit dan jahe bentuk tepung dan enkapsulasi dalam pakan terhadap jumlah mikroba usus halus ( $E$. coli, Salmonella sp., BAL, dan Lactobacillus sp. selama penelitian dapat dilihat pada Tabel 4 .

Hasil analisis variansi perlakuan penggunaan aditif pakan berupa campuran kunyit dan jahe dalam pakan yang diberikan dalam 2 bentuk yaitu tepung dan enkapsulasi tidak menunjukkan adanya perbedaan yang nyata terhadap jumlah $E$. coli, Salmonella sp., BAL, dan Lactobacillus sp. Hasil penelitian ini berbeda dengan hasil beberapa penelitian lain tentang antibiotik Khosravifar et al. (2014) melaporkan bahwa suplementasi tepung kunyit 1,5\%, lada hitam $1,5 \%$, jintan hitam $1,5 \%$ dan ketumbar 1 dan $1,5 \%$ dapat menurunkan jumlah bakteri bakteri coliform pada ileum burung puyuh. Kumar et al. (2010) melaporkan bahwa suplementasi senyawa aktif bawang putih sebagai growth promoter (G-PRO naturo) sebesar 250 ppm dapat menurunkan jumlah Salmonella sp. and E. coli di usus ayam pedaging, selanjutnya Aksu dan Bozkurt (2009) melaporkan bahwa penambahan antibiotik, minyak esensial, dan atau asam humat memberikan pengaruh yang nyata $(\mathrm{P}<0,05)$ menurunkan jumlah $E$. coli usus jika dibandingkan pakan kontrol. Perbedaan hasil penelitian diduga karena dalam penelitian ini

Tabel 4. Rerata jumlah E. coli, Salmonella sp., BAL dan Lactobacillus sp. di usus halus ayam pedaging dari pengaruh penambahan campuran kunyit dan jahe

(average of E. coli, Salmonella sp., BAL and Lactobacillus sp. Numbers in broiler intestine as influenced of curcuma and ginger mixer addition)

\begin{tabular}{ccccc}
\hline \hline $\begin{array}{c}\text { Perlakuan } \\
\text { (treatments) }\end{array}$ & $\begin{array}{c}\text { E. coli } \\
(\log \text { cfu/ml) }\end{array}$ & $\begin{array}{c}\text { Salmonella sp. } \\
(\log \text { cfu/ml) }\end{array}$ & $\begin{array}{c}\text { BAL } \\
(\log \text { cfu/ml) }\end{array}$ & $\begin{array}{c}\text { Lactobacillus sp. } \\
(\log c f u / m l)\end{array}$ \\
\hline $\mathrm{P}_{0}$ & 4,08 & 4,28 & 8,01 & 7,47 \\
$\mathrm{P}_{1}$ & 3,87 & 4,22 & 8,23 & 7,74 \\
$\mathrm{P}_{2}$ & 3,88 & 4,22 & 8,26 & 7,99 \\
$\mathrm{P}_{3}$ & 3,88 & 4,20 & 8,23 & 7,93 \\
$\mathrm{P}_{4}$ & 3,85 & 4,07 & 8,08 & 8,06 \\
$\mathrm{P}_{5}$ & 3,84 & 4,25 & 8,10 & 8,23 \\
$\mathrm{P}_{6}$ & 3,76 & 4,24 & 8,49 & 8,35 \\
$\mathrm{P}_{7}$ & 3,78 & 4,12 & 8,40 & 7,30 \\
$\mathrm{P}_{8}$ & 3,61 & 3,84 & 8,44 & \\
\hline
\end{tabular}


semua perlakukan pakan mengandung antibiotik yang ada dalam konsentrat yang digunakan, sehingga efek dari kunyit dan jahe tidak terlalu terlihat.

Uji antar kelompok perlakuan dengan uji kontras menunjukkan bahwa perlakuan penambahan campuran kunyit dan jahe tidak menunjukkan adanya perbedaan yang nyata $(\mathrm{P}<0,01)$ terhadap terhadap jumlah $E$. coli, dan Salmonella sp. dibandingkan penambahan campuran kunyit dan jahe bentuk enkapsulasi (Kontras 2). Penggunaan pakan basal yang mengandung antibiotik menyebabkan peranan kunyit dan jahe tidak terlihat pengaruh yang nyata dikarenakan antibiotik mempunyai kemampuan menekan dan membunuh bakteri. Besarnya rerata jumlah E. coli dan Salmonella sp. usus halus pada pakan yang diberi bentuk enkapsulasi meskipun secara statistik tidak menunjukkan perbedaan yang nyata, namun cenderung mengalami penurunan lebih besar dibandingkan diberikan dalam bentuk tepung. Pada pakan kontrol jumlah $E$. coli dan Salmonella sp. berturut turut adalah 4,08 log $\mathrm{cfu} / \mathrm{ml}$ dan 4,28 log cfu/ml, sedangkan pada bentuk tepung $3,87 \mathrm{log} \mathrm{cfu} / \mathrm{ml}$ dan 4,18 , pada bentuk enkapsulasi berturut-turut adalah 3,75 log cfu/ml dan 4,11 log cfu/ml. Hal ini menunjukkan bahwa penambahan campuran kunyit dan jahe terenkapsulasi mempunyai efek dalam menekan mikroba patogen lebih besar di dalam saluran pencernaan ayam dibandingkan pemberian bentuk tepung.

Perlakuan antar jenis penambahan campuran kunyit dan jahe bentuk tepung tidak menunjukkan adanya perbedaan yang nyata terhadap jumlah $E$. coli, dan Salmonella sp. (Kontras 3 - Kontras 5). Demikian juga dengan penambahan campuran kunyit dan jahe dalam pakan bentuk enkapsulasi dengan berbagai level tidak menunjukkan adanya perbedaan yang nyata terhadap jumlah E. coli, dan Salmonella sp. (Kontras 6 - Kontras 8). Namun ada kecenderungan semakin meningkat pemberian level kunyit dan jahe semakin sedikit jumlah $E$. coli, dan Salmonella sp. Adanya kecenderungan penurunan jumlah $E$. coli, dan Salmonella $s p$. ini memungkinkan untuk peningkatan level penggunaan kunyit dan jahe dalam pakan ayam pedaging. Penambahan kunyit dan jahe $0,8 \%$ memberikan pengaruh terbaik terhadap jumlah koloni $E$. coli dan Salmonella sp. di ileum mencapai angka terendah, sehingga jumlah bakteri patogen berkurang dalam usus berkurang. Penurunan jumlah koloni E. coli dan Salmonella sp. di ileum diduga karena adanya kandungan minyak atsiri, kurkumin dan oleorisin pada kunyit dan jahe. Ajizah (2004) menyatakan bahwa minyak atsiri dapat menghambat pertumbuhan dan mematikan bakteri patogen.

Uji antar kelompok perlakuan dengan uji kontras menunjukkan bahwa perlakuan penambahan campuran kunyit dan jahe tidak menunjukkan adanya perbedaan yang nyata terhadap jumlah BAL dan Lactobacillus sp. dibandingkan dengan pakan kontrol (kontras 1). Perbedaan yang tidak nyata disebabkan ada peranan antibiotik didalam pertumbuhan bakteri non patogen selain dari zat aktif pada kunyit dan jahe. Antibiotik berperanan dalam membunuh bakteri non patogen sedangkan zat aktif kunyit dan jahe menyebabkan pertumbuhan bakteri non patogen meningkat. Hasil ini berbeda dengan penelitian Tekeli et al. (2010) menyimpulkan bahwa pemberian suplemen ekstrak tanaman khususnya jahe meningkatkan jumlah bakteri non patogen, demikian juga Saki et al. (2012) melaporkan bahwa penggunaan acidifier dan fitobiotik secara nyata meningkatkan jumlah BAL dan menurunkan jumlah Enterobacteriaceae di ileum dan cecum ayam pedaging. Namun secara numerik data hasil penelitian ini terjadi peningkatan jumlah $\mathrm{BAL}$ dan Lactobacillus sp. pada usus ayam pedaging pada semua level pemberian campuran kunyit dan jahe dibandingkan kontrol.

Perlakuan penambahan campuran kunyit dan jahe bentuk tepung dalam pakan tidak menunjukkan adanya perbedaan yang nyata terhadap jumlah BAL dan Lactobacillus sp. dibandingkan penambahan campuran kunyit dan jahe bentuk enkapsulasi (Kontras 2). Namun ada kecenderungan pemberian bentuk enkapsulasi lebih banyak bakteri non patogen yang tumbuh dibandingkan yang diberi bentuk tepung. penambahan kunyit dan jahe bentuk tepung tidak berpengaruh nyata terhadap jumlah koloni Lactobacillus $s p$. Penambahan kunyit dan jahe pada level 0,4\% memberikan hasil terbaik dibandingkan dengan level $0,0,2,0,6$, dan $0,8 \%$ karena pada level $0,4 \%$ jumlah koloni Lactobacillus $s p$. di ileum mencapai angka tertinggi, 
sehingga minyak atsiri pada kunyit dan jahe dapat bekerja secara optimal.

Kondisi $\mathrm{pH}$ yang rendah di ileum akan menekan jumlah bakteri patogen dan meningkatkan bakteri non patogen, termasuk Lactobacillus sp. Minyak atsiri pada jahe dan kunyit yang terdegradasi di dalam usus halus dapat mempengaruhi keasaman usus dengan cara menurunkan $\mathrm{pH}$ usus dan mengakibatkan meningkatnya jumlah koloni Lactobacillus sp. Lactobacillus sp. memiliki kemampuan untuk menciptakan lingkungan asam yang dapat menghalangi pertumbuhan dari banyak jenis bakteri patogen.

Dari hasil penelitian ini diketahui bahwa pada semua perlakuan jumlah bakteri non patogen lebih tinggi daripada bakteri patogen. sehingga keseimbangan mikroba dalam usus terjaga keseimbangnya. Samadi (2004) dan Sjofjan et al. (2003) menyatakan keseimbangan antara bakteri non patogen dan patogen dalam saluran pencernaan mempengaruhi kesehatan ayam. Dominasi dari bakteri BAL ini karena bakteri Lactobacillus sp. tersebut menghasilkan antimikroba (bakteriosin) sehingga dapat menekan pertumbuhan Salmonella sp. dan E. coli. Hasil ini sangat penting karena Salmonella sp. dan E. coli merupakan bakteri yang sangat berbahaya. Wiryawan et al. (2005) menyatakan bahwa aktivitas antimikroba terhadap Salmonella sp. sangat penting peranannya dalam meningkatkan produksi ternak maupun mencegah terkontaminasinya produk-produk peternakan oleh Salmonella sp. Salmonella sp. merupakan bakteri patogen yang berbahaya yang dapat menyebabkan diare baik pada hewan maupun manusia.

Perlakuan antar jenis penambahan campuran kunyit dan jahe bentuk tepung tidak menunjukkan adanya perbedaan yang nyata terhadap jumlah BAL dan Lactobacillus sp. (Kontras 3 - Kontras 5). Demikian juga dengan penambahan campuran kunyit dan jahe dalam pakan bentuk enkapsulasi dengan berbagai level tidak menunjukkan adanya perbedaan yang nyata $(P<0,01)$ terhadap terhadap jumlah BAL dan Lactobacillus sp. (Kontras 6 - Kontras 8). Hasil penelitian ini berbeda dengan Dono (2013) mengatakan bahwa kunyit (Curcuma longa Linn.) meruapakan salah satu tanaman obat yang dapat digunakan untuk menggantikan antibiotik pada ayam petelur periode layer dengan memberikan respon yang baik terhadap pertumbuhan, produksi telur, status kesehatan dan karakteristik karkas.

\section{Kesimpulan}

Kesimpulan penelitian penggunaan campuran kunyit dan jahe bentuk enkapsulasi menghasilkan hasil yang lebih baik dibandingkan tanpa enkapsulasi dengan level optimum 0,8\%. Disarankan penggunaan campuran kunyit dan jahe dalam pakan ayam pedaging tidak digunakan secara bersamaan dengan penggunaan antibiotik agar efek positif kunyit dan jahe lebih terlihat.

\section{Ucapan Terima Kasih}

Penulis mengucapkan terima kasih atas support dana dari Kementerian Pendidikan dan Kebudayaan Republik Indonesia.

\section{Daftar Pustaka}

Ajizah, A. 2004. Sensitivitas Salmonella typhimurium terhadap ekstrak daun Psidium Guajava L. Bioscientiae 1: 31-38.

Aksu, T. and A. S. Bozkurt. 2009. Effect of dietary essential oils and/or humic acids on broiler performance, microbial population of intestinal content and antibody titres in the summer season. Kafkas Univ Vet Fak Derg 15: 185190.

Bird, J. N. 2006. Performance Improvement Following Enzyme Supplementation of Wheat and Barley Poultry Diets. Asia Pasific Vitamins and Fine Chemical, Animal Nutrition and Health. http://www.pjbs.org. Diakses tanggal 12 Januari 2012.

Chen, D. Y., J. H. Shien, L. Tiley, S. S. Chiou, S. Y. Wang, T. J. Chang, Y. J. Lee, K. W. Chan and W. L. Hsu. 2010. Curcumin inhibits influenza virus infection and haemagglutination activity. Food Chem. 119: 1346-1351.

Dono, N. D. 2013. Turmeric (Curcuma longa Linn.) supplementation as an alternative to antibiotics in poultry diets. WARTAZOA 23: 41-49.

Emamzadeh, A. N. 2010. The relationship between excreta viscosity and TMEn in SBM. World Acad. Sci. Engin. Technol. 71: 109-111. 
Garci'a, V., P. Catala'-Gregori, F. Herna'ndez, M. D. Megi'as and J. Madrid. 2007. Effect of formic acid and plant extracts on growth, nutrient digestibility, intestine mucosa morphology, and meat yield of broilers. J. Appl. Poult. Res. 16: 555-562.

Garriga, M., M. Pascual, J. M. Monfort and M. Hugas. 1998. Selection of lactobacilli for chiken probiotic adjuncts. J. Appl. Microbiol. 84: 125132.

Khosravifar, O., Y. Ebrahimnezhad, N. Maheri-Sis, R. S. D. Nobar, J. GhiasiGalekandi. 2014. Effect of some medicinal plants as feed additive on total coliform count of ileum in Japanese quails (Coturnix coturnix japonica). Int. J. Biosci. 4: 211-220.

Kumar, S., K. C. Sharadamma and P. M. Radhakrishna. 2010. Effects of a garlic active based growth promoter on growth performance and specific pathogenic intestinal microbial counts of broiler chicks. Int. J. Poult. Sci. 9: 244-246.

Lavinia, S., D. Gabi, D. Drinceanu, D. Stef, M. Daniela, C. Julean, T. Ramano and Corcionivoschi. 2009. The effect of medicinal plants and plant extracted oils on broiler duodenum morphology and immunological profile. Rom. Soc. Biol. Sci. 14: 4606-4614.

Malekizadeh, M., M. M. Moeini and Sh. Ghazi. 2012. The Effects of different levels of ginger (Zingiber officinale Rosc) and turmeric (Curcuma longa Linn) rhizomes powder on some blood metabolites and production performance characteristics of laying hens. J. Agr. Sci. Tech. 14: 127-134.

Natsir, M. H., Hartutik, O. Sjofjan and E. Widodo. 2013. Effect of either powder or encapsulated form of garlic and Phyllanthus niruri L. mixture on broiler performances, intestinal characteristics and intestinal microflora. Int. J. Poult. Sci. 12: 676-680.

Paul, S. K., G. Samanta, G. Halder and P. Biswas. 2007. Effect of a Combination of Organic Acid salts as Antibiotic Replacer on the Performance and Gut Health of Broiler Chickens. LRRRD. 19.
Pelicano, E. R. L., P. A. Souza, H. B. A. Souza, D. F. Figueiredo, M. M. Boiago and Carvalho. 2005. Intestinal mucosa development in broiler chickens fed natural growth promoters. Brazilian J. Poult. Sci. 7: 221-229.

Rahman, H. A. A., S. I. Fathallah, M. A Helal, A. A. Nafeaa and I. S. Zahran. 2014. Effect of turmeric (Curcuma Longa), fenugreek (Trigonella foenumgraecum L.) and/or bioflavonoid supplementation to the broiler chicks diet and drinking water on the growth performance and intestinal morphometeric parameters. Global Veterinaria 12: 627-635.

Saki, A. A., R. N. Harcini, E. Rahmatnejad and J. Salary. 2012. Herbal additives and organic acids as antibiotic alternatives in broiler chickens diet for organic production. African J. Biotech 11: 2139-2145.

Samadi. 2004. Feed Qualiy for Food Safety. http://io.ppi-jepang.org/files/inovasi. Diakses tanggal 24 April 2012.

Sjofjan, O., Aulani'am, Surisdiarto, A Rosdiana, dan Supiati. 2003. Isolasi dan identifikasi Bacillus sp. dari usus ayam petelur sebagai sumber probiotik. Jurnal IImu-IImu Hayati. 15.

Steel, R. G. D. dan J. H. Torrie. 1991. Prinsip dan Prosedur Statistika Suatu Pendekatan Biometri. Gramedia. Jakarta.

Tekeli, A., H. R. Kutlu, L. Celik and F. Doran. 2010. Determination of the effects of $Z$. officinale and propolis extracts on intestinal microbiology and histological characteristics in broilers. Int. J. Poult. Sci. 9: 898-906.

Van der klis, J. D., C. Kwakernaak and W. de Wit. 1995. Effects of endoxylanase add ition to wheat-based diets on physicochemical chyme conditions and mineral absorption in broiler. J. Anim. Feed Sci. 51: 15-27.

Wiryawan, K. G., S. Suharti, dan M. Bintang. 2005. Kajian antibakteri temulawak, jahe dan bawang putih terhadap Salmonella typhimurium serta pengaruh bawang putih terhadap performans dan respon imun ayam pedaging. Media Peternakan 28: 5262. 
Muhammad Halim Natsir et al. Penggunaan Kombinasi Tepung Kunyit (Curcuma domestica) dan Jahe

Zhang, K. Y.. F. Yan, C. A. Keen and P. W. Waldroup. 2005. Evaluation of Microencapsulated Essential Oils and Organic Acids in Diets For Broiler Chickens. Poultry Science Departement. University of Arkansas, Fayetteville. 